„Bohemistyka” 2020, nr 1, ISSN 1642-9893

Svatava URBANOVÁ

DOI: $10.14746 /$ bo.2020.1.5

Ostravská univerzita

\section{Komiksové trilogie o životě Romů a romské identitě (romipenu) - knihy s hybridními žánrovými znaky*}

Keywords: social problems, stories of Roma, comics trilogy, hybrid geners, sociological aspect

Klíčová slova: společenská problematika, př́iběhy Romů, komiksové trilogie, hybridní žánry, sociologické aspekty

\section{Abstract}

Stories about Roma (for example, Děvčátko, rozdělej ohniček Make A Fire, My Girl by Martin Šmaus), works by Romani authors written in Czech and Romani, published for example in the publishing house KHER, as well as portraits of Romani personages can help us better understand Romani mentality and culture. The two comic trilogies $O$ pribjehi On Stories (201) and Nejisté domovy Uncertain Homes (2016) deal with a range of current social problems, based, however, on sociological research and the authentic narratives of the particular characters. The stories are attractive in terms of their art, specifically in the form of comics. The Romani scholar Markéta Hajská and the social anthropologist Máša Bořkovcová, who cooperate with leading comics artists (for example Vojtěch Mašek), are behind the origin of the project. Six volumes with a remarkable content gradually came into being dealing with the fates of six Roma of different generations and social origin. The works have a certain civility, authenticity and objectivity, while at the same time helping the reader obtain an improved understanding of Romipen (Romani identity), and are marked by a distinct artistic style and the hybrid character of the genre features.

$\mathrm{K}$ lepšímu porozumění romské mentalitě a romské kultuře mohou posloužit nejen př́běhy o Romech (napřx. Děvčátko, rozdělej ohníček od Martina Šmause), tvorba romských autorů, psaná v češtině nebo romštině, vydávaná např v nakladatelstvi KHER, ale také portréty romských postav. Dvě komiksové trilogie O přibjehi (2010)

* Studie je částečným výstupem z projektu SGS01/FF/2018 Vybrané žánrové a subžánrové proměny $v$ současné české literatuře II. a Nejisté domovy (2016) zpracovávají řadu aktuálních společenských problémů, přitom podloží jsou sociologické průzkumné sondy a autentické narativy jednajících postav. Zpracování látky je zpř́stupněno umělecky, navíc komiksově, v obrazovém narativu. U zrodu projektů stojí romistka Markéta Hajská a sociální antropoložka Máša Bořkovcová, které pro spolupráci získaly přední komiksové tvůrce (např Vojtěcha Maška). Vzniklo postupně šest svazků s pozoruhodným obsahem, pojednávající o šesti osudech Romů odlišného generačního a sociálního původu. Zaujmou svou civilností, autenticitou, věcností, prritom vedou čtenáře $\mathrm{k}$ lepšímu pochopení romipenu (romské identity), vynikají odlišným výtvarným rukopisem a hybridností žánrových znaků.

České komiksové trilogie ${ }^{1} \mathrm{~s}$ romskou tematikou, které vznikly ve druhém desetiletí 21. století, dostaly názvy O přibjehi (2010) a Nejisté domovy (2016). Svou širší čtenářskou odezvou jsou srovnatelné snad jen s proslulým českým komiksovým románem Alois Nebel (2003) autorů Jaroslava Rudiše a Jaromíra 99. Spojujícím prvkem zmiňovaných děl se stávají jejich tvůrci, nebot' Jaromír 99 a Vojtěch Mašek, scenárista a kreslír romské trilogie, patří k tzv. generaci Nula. ${ }^{2}$ Svou působnost v novější české literatuře projevili komiksoví tvůrci osobitým a těžce zaměnitelným rukopisem, navíc se námětově nevyhýbají ožehavé společenské problematice, soužití majoritní společnosti s romským etnikem. Zatímco v zahraničí se komiks již dávno stal rovnocenným žánrem, v českém literárním a kulturním prostoru se prosazuje přece jen povlovně, zvláště když se prezentuje jako grafická novela, subžánr historické, společenské nebo životopisné větve.

${ }^{1}$ Nepoužíváme termín grafická novela, nebot’ v češtině má pojem grafický poněkud odlišný význam než $\mathrm{v}$ angličtině, stejně jako novela není shodným označením jako u nás. Přitom se nevžil ani termín vizuální narativ. Jestliže v této studii uvažujeme o komiksové trilogii, používáme sice terminologii literární vědy a dovoláváme se k rozsahově-formálnímu kritériu, ale zároveň odkazujeme k novosti českého komiksu, protože máme na mysli rozsáhlejší útvar se závažným obsahem a promyšlenou strukturou.

2 Poprvé byla takto označována nová vlna mladých autorů českých komiksů v předmluvě Tomáše Prokůpka v knižní antologii Generace Nula 2010. Citováno z publikace Nový český komiks... 2012, s. 21. 


\section{Srovnání se zahraniční tvorbou}

České romské trilogie nebudeme srovnávat s francouzskou komiksovou sérií Gipsy (2002-2003; knihy: Smolderen, Gipsy 2003a, b, c, 2004), která je výsledkem spolupráce švýcarského kreslíre Enrica Mariniho a belgického scénáristy Thierry Smolderena (v českém překladu ji známe zásluhou Tomáše Bicana a Richarda Podaného). Její modus je odlišný. Pojem modus používáme proto, že sledujeme intermediální zpracování společensky naléhavých témat. Rozdílnost v př́istupech francouzsky psaného zpracování spočívá rovněž v hodnotovém systému a mentální specifičnosti (Ševčíková 2008, s. 35-41). Obě české ,romské trilogie” vznikly ve snaze popularizovat a zpřístupnit romskou kulturu a odlišné životní pozice Romů. Vztah k Romům je budován na principech poznávacích, je doprovázen snahou přiblížit se prostředí, v němž se pohybují, byt' to nemusí být jednoduché a jednoznačné. Hlavní hrdina Gipsy je naopak vylíčen jako věčný rebel, nihilista a násilník, vyznačuje se ,neutlumitelnými emocemi”, ,nezvládnutelným násilnickým chováním”, které je podle autorů dokladem etnické odlišnosti. Podle Veroniky Ševč́́kové se francouzský psaný komiks stal ideově značně diskutabilní. Na jeho př́ikladu se poukazuje, jak v současné moderní evropské společnosti přežívají stereotypy v myšlení, kde vzniká živná půda pro rasistickou předpojatost na jedné straně, apatie nebo agresivita na straně druhé.

\section{První české komiksové zpracování}

První české komiksové zpracování romské látky se společným názvem $O$ přibjehi (2010) nezastírá pragmaticko-recepční zřetel. Východiskem je odborný př́stup $\mathrm{k}$ romské problematice, sběr tzv. oral history, nebot' autory projektů zajímají prosté lidské príběhy a autentické výpovědi Romů různých generací. Autoři vybírají takové postavy, které se stejně jako v jiných druzích mimetického umění představují jako klíčové. Předností komiksů se stává, že je vnímáme jako př́iběh odvíjející se před námi. V prvním souboru $O$ přibjehi se svazky nazývají Albina, Ferko, Keva podle vlastních jmen hrdinů. Jedná se o běžný komiksový postup (viz Alois Nebel), stejně jako se vžilo zůstat u jednoho vzhledu postavy (fyziognomie, anatomické proporce, oblečení), aby byly postavy snáze rozpoznatelné a zvýraznily se tím některé jejich povahové a tělesné rysy. Tvůrci komiksů mohli vyhotovit portrétní fotografie jednajících postav a pořídit zvukové nahrávky společných rozhovorů, a tak eliminovali již jednou řečené a vraceli se k uzlovým životním bodům.

V komiksových svazcích vystupují nejen Romové, ale také další reálné postavy, včetně terénních výzkumných pracovníků (účinkuje v nich např. romistka Markéta Hajská, sociální antropoložka Máša Bořkovcová). ${ }^{3}$ Nastolené situace jsou založeny na překvapujících životopisných faktech romských hrdinů, které objasňují rodové vztahy, vžité vzorce chování, předsudky, city a touhy postav. V pozadí se odvíjí řada společenských a historických proměn, včetně rozpadu Československa, ekonomické krize doprovázené ztrátou zaměstnání a dalšími jevy. Cílem těchto komiksů je zachytit a zprostředkovat recipientovi aktuální tematiku. Malá lidská dramata s reálně př́tomnou situací, dílčí fakta, osudy i osoby doplňují představy o Romech. Jejich životy nejsou idealizovány, neskrývají se krajní (negativní) emoce, nicméně je zřejmé, že se jedná o moderní beletristické biografie. Hrdinou se zde stávají osoby z hlediska velkých dějin nevýznamné, ,jinaké”, prítom jsme seznamováni jen s vybranými životními epizodami, které podle pozice jednajících postav sehrávají významnou roli pro zvolené modality.

V cyklu Nejisté domovy, v němž se zachycuje dětství a dospívání romských hrdinů generace sociology označované jako „Z”, nebot' jsou narozeni v novém miléniu, působí na vnímatele zobrazení sociálního prostředí, z něhož děti vzešly. Maškovo černobílé řešení v prvním souboru odpovídá zvolené dokumentární poloze, je v rov-

${ }^{3}$ Je absolventkou pražské romistiky na FF UK. Vydala knihu Romský etnolekt češtiny: Př́ipadová studie (Praha: Signeta, 2007). Zabývá se v ní materiálem dialektu části romské komunity v pražské čtvrti Smíchov. Dovídáme se tak o existenci specifiky romské podoby mluvené češtiny. 
nováze s textovými pasážemi. Pro druhý soubor je příznačné posílení barevnosti, které lépe navozuje škálu pocitů, kterými hrdinové procházejí, způsoby, jak (ne)překonávají překážky. Svazky zahrnují smutek, nesoulad i nesouhlas s místem, kde se nacházejí. Jedná se o př́iběhy dětí mnohdy s vývojovou dysfázií, těžce vychovatelné.

V obou komiksových souborech dochází ke kombinaci odborné (vědecké) metody s metodou modálně specifikovanou tak, že výsledek má blízko k uměleckému zobrazování dějů s cílem postihnout spletitější vztahy mezi romskou a neromskou komunitou, mezi samotnými Romy, v soužití Čechů a Slováků i se vztahem k romským komunitám v zahraničí. Na jednom pólu tedy stojí výzkumná strategie, která je založena na vstřícnosti a všímavosti, probíhá v určitém časovém úseku, berou se v úvahu sociologická paradigmata (sociognoseologická a institucionální), na druhé straně se objevuje snaha vytvořit komiksově sdělné curriculum vitae zvolených postav. Vypravování životních příběhů polarizuje mezi pólem faktografickým a populárně beletrizujícím. Zatímco v prvním sdělovacím okruhu se děj odvíjí zpomaleněji, nebot' se uvádějí širší souvislosti, svazky mají své prology a epilogy, ve druhém okruhu mají převahu protikladné emoce a scény a výjevy se odehrávají zrychleně. Zvláště ve druhém souboru reagují romské děti živelně, pudově, dostávají se do nečekaných střetů s vychovateli a pěstouny, nechtějí se přizpůsobit zavedenému režimu, trpí osobnostními poruchami, někdy se cítí jako nemilované, odstrkované a podceňované.

Autoři komiksů sice ponechávají vypravěčskou volnost naratorům, nebot' se ve výsledku jedná o bytostně / ontologicky osobité reflexe, které navíc disponují vícevýznamovostí, uvědomují si však, že mohou narazit na subjektivní bariéry zobrazovaných postav. Např. pro Albínu je časovým předělem osudová láska $\mathrm{k}$ muži neromského původu. V podstatě jí vedený dvojí život vrcholí manželovou sebevraždou a odchodem z východního Slovenska na severní Moravu. Autoři komiksů museli nejdříve získat důvěru a souhlas jednajících postav s beletristickým zpracováním. Je pochopitelné, že se při něm zvýší funkční a sémantický rozptyl a může dojít $\mathrm{k}$ rozkmitu mezi protik- ladnými póly. Neví se, jak budou reagovat. Vzájemný dialog byl však založen na korektnosti, vzájemné důvěře, prrátelskosti, vstřícnosti, tolerantnosti. Jako celek působí obrázkový narativ důvěryhodně, ctí se individuální pozice postav. Nementoruje se, nehodnotí, ale ani neodsuzuje. Nezáleží na tom, jakým jazykem mluví (slovensky, česky, romsky), zda s větší či menší frekvencí používají onomatopoie (mimochodem frekventovaněji jsou zastoupena v Nejistých domovech).

Trilogie jsou ojedinělé nejen v tom, že jednotlivé svazky vznikly z iniciativy osvědčeného autorského týmu složeného z odborně erudovaných pracovníků, kteří mají znalosti ze sociologie, antropologie, speciální pedagogiky a dalších kognitivních věd, ale neopomíjejí se ani umělecká forma beletrizovaného zpracování tématu a výsledný komiksový tvar, který nutně začneme vnímat esteticky. Obě trilogie se tak stávají pozoruhodným fenoménem, nebot' se nejedná jen o individualizaci postav, ale o společenský obraz, na němž se podílejí humanitní vědci a umělci, scenáristé, výtvarníci, kreslírí, muzikantka a raperka, osvědčení tvưrci, kteří uspěli v české i mezinárodní konkurenci (např. Vojtěch Mašek a Lela Geislerová).

Výchozí myšlenkou Máši Bořkovcové a Markéty Hajské byla snaha zachytit životní př́běhy obyčejných Romů v osadách na Slovensku, protože po povodních v roce 1998 sem přicházeli členové české humanitární organizace Člověk v tísni. První díl trilogie Albína byl úspěšně dotvořen výtvarníkem a scénáristou Vojtěchem Maškem, jenž kombinoval hodnověrné fotografie s malbou a kresbou, použil širokou kresebnou škálu. Maškova práce byla právem oceněna a on se stal laureátem nejvyšší komiksové ceny Muriel. Komiksová zpracování romské problematiky se postupně stávají úspěšnými transpozicemi seriózního sociologického a antropologického výzkumu. Jak jsme již uvedli výše, pohybují se na hranicích vědních oborů i uměleckých druhů, výsledný tvar bychom mohli označit jako synkrezi (Šidák 2013, s. 114). Propojuje se v nich text (literatura) a obraz (výtvarné umění), srůstají v něm různé umělecké druhy, které typologicky odpovídají přechodům do dalších kódů (Mauthauser 1999, s. 102), obrázková pásma stř́idají Maškovy celostránkové malby. 


\section{O přibjehi - výpovědi o nedávné minulosti i současnosti}

Př́iběhy jsou vybrány tak, aby se čtenář seznámil s některými představiteli Romů, vypořádal se se složitou problematikou, která je stále živá a pro značnou část romské i neromské populace také velmi citlivá. Je jí jinakost a vztah minority $\mathrm{k}$ majoritě, doprovázený sebeuvědoměním a romipenem (romskou identitou). $V$ první sérii ilustrativně převažuje kresebný černobílý kontrast, což většinou souvisí s romským vnímáním života a světa (Jařabová, Davidová (eds.) 2000), ve druhé sérii s názvem Nejisté domovy dochází k modální specifikaci, kresebně se postupuje také s použitím počítačové techniky.

V obou trilogiích se zúročuje scenáristická narativní forma, propojuje se několik žánrových architextů (společenská novela, vývojový př́běh, klukovský a dívčí příběh), obrazově podpořených sekvencemi, které připomínají filmové postupy (Foret 2012, s. 86). Vědecká báze, odborná podlož, kterou zejména aplikuje Vojtěch Mašek, respektuje cíl a poslání publikací, ale nerezignuje ani na osobitost, jedinečnost a neopakovatelnost životních příběhů vybraných hrdinů. Při realizaci druhé řady - trilogie Nejisté domovy - byl přizván k spolupráci František Loubal, dále se uplatnil př́stup specializovaného komiksového autora Marka Pokorného a malirirky a scenáristky Lely Geislerové, sestry známé české filmové herečky Aňi Geislerové. Vizuální efekt a grafické provedení v obou sériích jsou natolik působivé, že čtenář již při prvním čtení ocení „atmosférické výjevy” klíčových momentů.

Z rozboru svazků Albína a Ferko, kde se prolíná řada významových rovin, vyplývá, že lze postihnout jak různé časové děje, tak osudy postav, které charakterizuje zevnějšek, způsob obživy i jazyk. V komiksech prvního souboru se stává společným jmenovatelem př́buzná dějinná zkušenost, zaujmou výběr motivů i způsob zpracování (linearita a sukcesivita). Čtenář rozpozná, kdy se Ferko snaží vytvořit co nejlepší dojem o sobě i olašských Romech, vypomáhá si fabulací. Všude tam, kde umocňuje význam svého rodu a zdůrazňuje pozici v přirozeném světě, vypráví tak, že se ocitá blízko mýtu nebo pohádky. Fikční svět chápeme ve shodě s Ryanovou (2015) nebo se Stanislavem Rakúsem (2015) - jako ontologicky novou skutečnost. Zvláště v př́iběhu o Ferkovi, kde se objevují fikční př́iběhy známé z vyprávění předků, vznikají samostatné celky, které nejsou detailně rozpracovány do obrázkového narativu, avšak vždy jsou dostatečně srozumitelné. Mění se v nich spíše textová stylizace. Vytvář́ se jako kdyby odstup od př́tomného světa a Ferko místy připomíná lidového vypravěče. Stává se mluvčím a hlavní postavou zároveň, vše vztahuje $\mathrm{k}$ sobě a své rodině. Postihnout způsob komunikace v tomto specifickém okruhu výpovědi nelze bez vztahových rámců. Rozpoložení postav se zrcadlí ve výrazné gestikulaci a mimice, avšak širší kontext musí být vyjádřen nedlouhými údernými větami, aby děj nabyl spád. Žánr komiksu se v těchto dvou souborech projevuje jako svébytné médium, nepostrádá nosný obsah, ale nechybí v něm ani umělecký rozměr. Námi analyzované romské komiksové trilogie jsou založeny na podnětnosti sociologického výzkumu, nejsou primárně záležitostí výtvarnou, avšak tím, že se výtvarné složky ujali talentovaní výtvarníci, považujeme uměleckou (komiksovou) realizaci tématu za rovnocennou.

\section{Generační zastoupení postav}

V knihách $O$ přibjehi vystupují v jednotlivých životních výpovědích jako hlavní aktéři tř̆i Romové různých generací. Odlišují se věkem (Ferko je šedesátiletý, Albína pětačtyřicetiletá, Keva má dvacet let). S Ferkem se dostáváme do severních Čech a cestujeme až do Švédska, s Albínou se pohybujeme v romských osadách východního Slovenska a v Javorníku na severní Moravě v 90. letech 20. století, Keva prožívá dětství a dospívání v polistopadovém čase, vyrůstá na pražském Smíchově, později se dostává do vesnic kolem Prahy. Jejich názory, životní styl, způsoby trávení volného času jsou generačně značně rozdílné. Ve Ferkovi prokazují Romové starší a střední generace vzájemnou solidaritu, projevují respekt a úctu k starším členům romské komunity. Staří žijí s mladými, jsou vážení a ctění, nebot' mají 
větší životní zkušenosti a nabyli moudrý rozhled. Ferko stojí vždy za svou rozvětvenou rodinou, neobrací se však zády k nikomu. Když někdo onemocní, snaží se mu pomoci, vyslechnout ho a porozumět mu. Zeširoka mluví a je rád, když mu ostatní s respektem naslouchají. Stává se vzorem pro Romy - slovem i př́kladem. Opakovaně vyzývá, aby si vážili jeden druhého a uctívali zkušené, aby nepřestali pracovat. Vystupuje jako moudrý a spravedlivý muž s vysokou morální autoritou, jenž ctí vnitřní romské zákony a jako ostatní se podřizuje rozhodnutí ,romského soudu”.

Střední generaci slovenského romského etnika zastupuje krasavice Albína. Převyšuje okolí svou vrozenou inteligencí, svobodomyslností, snahou vymanit se z tradičních pout rodinných vazeb a submisivního postavení ženy. Romové považují své manželky za svůj majetek, mohou je beztrestně a nezdůvodněně mlátit. Příběh Albíny v osadě Hermanovce na východním Slovensku je viděn ze čtyř rozdílných zorných úhlů: z pohledu Albíny, očima českého humanitárního pracovníka Karla, který přichází do osady během povodní v roce 1998, pohledem skeptického českého antropologa Jardy a nadšené pražské studentky Kláry. Nejmladší generaci zastupuje Keva, o které pojednáme později.

\section{Nejisté domovy}

První trilogie $O$ přibjehi je ojedinělá nejen zvolenou komiksovou uměleckou formou, ale také tím, že příběhy o dospělých Romech vycházejí ze životních zkušeností tří po sobě jdoucích generací, které částečně žily v Česku a na Slovensku. Hrdinové reprezentují typické generační romské představitele. Svazky $O$ přibjehi jsou navíc unikátní vypravěčovým postojem, protože o svém životě protagonisté vyprávějí jakoby sami a nechávají na čtenáři, aby sám přišel na to, jakou pozici zaujímají. Nebylo donedávna obvyklé, abychom se setkávali s tematizací romské identity a se vzpomínkami Romů, natož zprostředkované v komiksové podobě. Druhá trilogie Nejisté domovy navazuje na osvědčený postup, avšak soustřed'uje se na osudy těch, kteří prošli ústavy, žili v dětských domovech. Tři romští reprezentanti vypovídají o svých trápeních a sociální izolaci, kterou si zkraje neuvědomovali. Vrací se ve svých vzpomínkách k dětství a dospívání, které bylo přece jen trochu jiné než svět jiných vrstevníků. V době, kdy brali rozum, v letech, která si již pamatují, byli obklopeni vychovatelkami v dětských domovech, nevybavovali si, jak rodiče vypadají. Někteří se naučili ignorovat okolí a proto, že se obávají zklamání, nenavazují dlouhodobá prrátelství s neromskými spolužáky. Michal ve svazku Nebud' jak gádžo! (2016) žije od svých dvou let v dětském domově ve Frýdlantu v Čechách, Honza Oračka ze Silnějšího než někdo v Husinci a pak v řadě dalších domovů, Lili z knihy Lili a dvě mámy byla odebrána matce ve čtyřech letech. (Názvy měst, míst, jména a přijmení protagonistů byly na přání hrdinů změněny nebo vynechány.) K pěstounům se Lili dostává až ve svých deseti letech. „Druhá máma” dobře ví, že zbývá málo času k tomu, aby dívence vštípila, co bude v majoritní společnosti potřebovat. Stř́ídají se diferencované úhly pohledu, nebot' romské děti, a to bez ohledu na to, zda se jedná o chlapce nebo dívku, o slabší nebo silnější intelekty, s talentem (např. muzikálním) nebo bez něj, zdravé nebo s vážnějšími poruchami chování, prahnou spíše po romské komunitě. V komiksovém zpracování jsou dokonce naznačeny některé vývojové a tvarové modifikace ožehavé sociokulturní tematiky, která neobchází segregaci - integraci a inkluzi. Patř́ ke cti autorského týmu, že není vedena snahou idealizovat a zjednodušovat. Odkrývají se různorodosti, nezatajují se lidské charaktery od empatie a snahy pomoci po lhostejnost, vypočítavost až surovost, těžkosti a problémy.

\section{Ferkův životní příběh - příklad z dějin olašských Romů}

Vrat'me se k první trilogii O přibjehi (Histoires), která byla v roce 2011 Milenou Fučíkovou přeložena do francouzštiny a byla vydána v Bussy-Saint-Georges. Začneme trilogií, která nese název Ferko. Na první pohled se zdá, že František Makula zvaný Ferko pouze vypravuje, co slyšel od svého dědy. Autoři trilogie ponechávají textu určité 
příznaky: směšují se v nich zdroje a asociativní přiřazování motivů, které neposilují vztahy vnitrotextové, ale vypovídají více o vnětextových relacích. Ferko ve svém vyprávění neustále odbočuje. Opakovaně zdůrazňuje, že pochází z váženého rodu, že otcova prestiž byla spojena s kovářstvím, nejtypičtějším řemeslem, kterým se Romové po staletí živili, že děda z otcovy strany proslul svým bohatstvím, které získal obchodováním s koňmi a prasaty vyváženými do Holandska. Babička patřila $\mathrm{k}$ významné mad’arské muzikantské rodině. Souhlas k ženitbě a výkupné nevěsty činily tehdy 300 tisíc a navíc se muselo přidat půl kila zlata. Jedná se o starý zvyk, který se respektuje dodnes. Jestliže ženich finanční obnos nemá, ale jeho nevěsta se ženichově otci zamlouvá, pak výkupné zapůjčí příbuzní (rodiče, bratři a bratranci) a k svatbě dojde. V opačném př́padě se novomanželkou nestane. Po svatbě však žena odchází z domu a zcela se přizpůsobuje manželově rodině.

Rodová hierarchie a rodové tradice jsou v myšlení Ferky a jeho generace pocit’ovány velmi silně, což koresponduje se sociální stabilitou a vnitřní kulturní integritou př́slušníků starší generace. Za životní vklad (duchovní a symbolický) považuje Ferko svůj rod, vazbu na předky, nebot' to je základ romského společenství a jeho největší hodnotu vidí, když někde mohou být pospolu. Rozvětvený rod je zdrojem obrody a síly, stává se zárukou společenského úspěchu. V prvním př́iběhu s názvem Ferko nejde jen o vzpomínky, ale také o události, označované Alexandrem Kratochvilem jako false memory (Kratochvil 2015, s. 3). Tento termín uvedl ve své recenzi komiksového románu Alois Nebel. Podstata tkví v tom, že ,se totiž v paměti jedince smývá hranice mezi smyšlenými, resp. zprostředkovanými událostmi a událostmi skutečně prožitými” (Kratochvil 2015, s. 13). Především u zmíněného prvního svazku Ferko se smývá předěl mezi tradovanými ústně podanými historkami. Ferko vystupuje jako kladný hrdina, zprostředkovává př́běhy o svých dávných supermanských fyzických schopnostech, které dává k dobru. Např. když uvádí, jak byl skvělým fotbalistou, jak hrál se svým manšaftem proti šedesátce hráčů posbíraných z Prešova, Sabinova, Lipan a během půl hodiny prohráli hostu- jící 6:2, 7:2. Podle Ferky bohatství dědy Mat'ase (Matěje Makuly) bylo tak obrovské, že kam náhodou dorazil a chtěl přenocovat, tam si dům se zařízením přímo koupil.

Každému detailu věnují autorky pozornost. Např́iklad vlastní jméno hlavního představitele se stává nepř́mou charakteristikou hrdiny. Propria romských postav i přezdívky romských mužů a žen jsou důležitá pro odlišení společenského místa. Ferko je statný šedesátník, patř́̀ k olašské komunitě, která žije v křest'anském prostř̌edí a převzala z něj formálně řadu zvyklostí a obyčejů. Mezi nimi je jméno katolického světce Františka. Z vnější charakteristiky upoutá nejen zobrazení zavalité postavy, ale především sklon k ležérní eleganci. Ferko chodí zásadně v obleku a nosí klobouk. Jedno romské př́ísloví říká: „Každý je Romem, kdo klobouk nosí”. V jeho postojích se zračí určitá rozvážnost, gesta jsou pomalá, ne-li vznešená až obřadní.

Ve Ferkově vyprávění je zastoupena nadsázka, možná až furiantství, nechybí citová exaltovanost, apelativnost a tendence $\mathrm{k}$ předvádění se. Přes volnost a zpomalenost jeho toku vyprávění, bohatě prokládaného romštinou, postřehneme četnou proměnlivost postojů v konkrétních situacích, kdy může působit upovídaně až užvaněně, téměř „hrabalovsky”, vystupuje hrdě a zároveň nezávisle. Netají se tím, jak jsou pro něj a jeho příbuzné důležité peníze. Rád zdůrazňuje, že jeho příbuzní v zahraničí jsou milionáři. Představují nejen prostředek k obživě, ale získává se jimi přirozená autorita uvnitř romské komunity. Peníze podle něj ovšem slouží především k tomu, že Roma osvobozují. Může pohostit rodinu a přátele, bavit se tak dlouho, dokud to jde. Nezáleží na způsobu, jak kdo k penězům přišel. Ferko se např́iklad podivuje, proč by někdo nemohl pobírat invalidní důchod již ve svých dvaceti letech. Naopak se brání, když se romský taxikář ve Švédsku ptá, zda účelem př́ijezdu jsou kapesní krádeže, a on se dušuje, že patř́ k jiné romské vrstvě:

\section{A.}

Te marel ma o sunto děl, ame kodo či keraši anáre Rom či Čoren, te prachos ma! At' mě Bůh potrestá, my tohle neděláme! Naši Romové nekradou! At’ mě pohřbějí! (O pribjehi; Ferko, 2010). 
V trilogii $O$ přibjehi se uplatňují hlavní a vedlejší postavy, které se podílejí na rozvíjení děje a utvářejí smysl vztahů, podílejí se na modelování postav s osobitou romskou mentalitou a s pozůstatkem nomádského způsobu života. Ten sice v 60. letech 20. století na území Československa skončil, avšak vnitřní nutkání ke střídání míst zůstává. Ferko je nositelem spíše vžitých a tradovaných vlastností Romů, jeho vyprávění připomíná memoráty. V komiksovém podání jeho života se často objevuje nepř́má situační charakteristika, založená na jednání a důležitosti toho, co kdo a kdy řekl. Ferko je sice značně sebestředný, ale dovede druhé zaujmout. Nemá nikde stání, opakovaně se stěhuje, nečekaně odchází a vrací se, stále někoho navštěvuje. Spojením několika zorných úhlů dojdeme k zjištění, že je ve společnosti Romů oblíbený zejména proto, že své osobní životní zkušenosti podává přesvědčivým způsobem, umí potěšit i poradit, aniž by ho o to někdo žádal, vyjadřuje hlasitou radost při pouhém setkání s jiným Romem. Ferko dokonce přesvědčí autory komiksu, aby s ním jeli do Švédska, kde několik let žil, a vypráví o tom, jak ho tam všichni cikáni znají. Když už sedí v letadle, jen tak prohodí, že je šestnáct let neviděl a nemá adresy. Neumí anglicky a neovládá švédštinu, ale ani na chvíli nepochybuje, že se domluví.

B.

Jablonec, podnájem u soukromníka. 23. června 2007

„Vyhovovalo by mně, abychom jeli v létě do Švédska."

„Ukaž! - Dybysi chtěla.”

„Tak pojedem?"

„Za těma vašima př́ibuznejma?"

„To ti př́sahám! A když už tam dopadnem, tak se neboj, já Tě vodnesu u svý rodiny, uvidíš, jak se krásně uměj bavit! Ty řeči vzacný. Od Halmo až do Stockholmu mě poznaj všechny Romi!"

Jako kdyby se chtělo sdělit, že „Rom druhého Roma ve světě vždy najde, nebot' jsou všichni nějak spojeni”. Když k tomu skutečně dojde, Ferko pronese v rodině slavnostní slova. Projeví úctu a vděk Bohu, který dovolil, aby se ve zdraví setkali:
C.

Bůh dal tuto chvíli, že jsem dorazil podívat se na rodinu! Chvála Bohu! At nám celé rodině pomáhá Bůh i Panenka Maria a Bůh žehnej i těm, kteří nejsou spolu s námi! Moc si vážím toho, že jsem přijel mezi Vás. At dá Bůh! (O přibjehi; Ferko, 2010).

Ferkova empatická schopnost promluvit se správnou intonací se odráží v syntaktické skladbě věty a patosu. Sám neumí ani př́liš psát, mluví zvláštní češtinou, nesnaží se zdokonalovat, nečte, avšak dovede vycítit, jak má promluvit, odpovídat a vysvětlit věci až záhadné a pro okolí až tajemné. Ferkova mluvená řeč je směsicí různých stylů (viz B). Nevadí ani to, že se jedná o spletenec romštiny, zkomolené slovenštiny a obecné češtiny (viz A, C). Jestliže je Ferkova promluva náhodou vedena v češtině, má jeho výpověd',specifickou" morfologii a syntax, vyznívá jako řeč cizince (viz B). Je-li rozhovor veden v romštině, umístuje se pod ním český překlad do bublin. Do emocionálně podávaných a zprostředkovaných epizod jsou celkem přirozeně vkládány kapitolky s názvy Jak př̌išli Romové do Rožkovan nebo O bratranci Bakrorovi, v nichž jsou potvrzovány zobecňující povahové rysy Romů a jejich začleňování do společenských struktur. Nejedná se o komplex složitějších myšlenkových souvislostí, spíše o komunikativní pamět', nebot' výpověd' v sobě nese a uchovává historii vždy jedné zástupné romské rodiny.

Ferkủv životní př́iběh je komponován tak, že se v něm prolínají současné historické děje se vzpomínkami na poválečné dětství. Motivy, které se zde objevují, jsou řazeny reverzibilně a hierarchicky, podle toho, jaký dojem chce za sebou zanechat. Třeba rád zdůrazňuje, jak byl od dětství veden k pracovitosti, připomíná, jak byl na něj otec pyšný, když hrál dobře fotbal, jak bylo v rodině oceňováno, když se jednalo čestně a stálo se za svým slovem. Projevuje úctu k rodičům, pomáhá nemocnému sourozenci, tady bratrovi Jožkovi aj. Dodejme, že jsou to většinou muži, s jejichž zodpovědností a postoji se srovnává. Ženy vykonávaly požadované, někdy od něj nečekaně odešly a již se nikdy nevrátily. Ferkovy př́klady ze života nebo vyprávěné př́běhy nemusí mít vždy začátek a konec, někdy se vytrácí pointa. Lokalita nebo pamět' místa (topos místa) není rozhodující, vnímání do- 
mova je svébytné, nebot' je symbolické. Tak jako poznání neprobíhá na bázi kognitivní, spíše je neseno na vlně emocionality, tak domov je spojen s lidmi a je vnímán jako vertikála sui generis, kolem níž se s různou mírou intenzity mohou vyskytovat další významy. Je až nápadné, jak se Ferko opakovaně přemíst'uje, stále někam jezdí a dlouho nezůstává na stejném místě. Graficky je řada vnitřních vztahů zdůrazněna tak, že životopisné uzlové momenty jsou na některých stránkách žlutě vyznačeny a mohly by se číst samostatně.

Připomeňme si některý další charakteristický rys. Ferko jako invalidní důchodce chodí s francouzskými holemi, prošel několikerými operacemi. Nedovídáme se, kde byl operován, není to pro něj zřejmě podstatné, spíše ho zajímá nemocniční prostředí než místo nebo město. Se svým zdravotním stavem se smíŕil, vše přijímá zcela klidně. Až úsměvně působí, když opakovaně a rád vzpomíná na svůj nemocniční pobyt spojený s úctou a respektem zdravotnického personálu. Spíše než o pamět' míst (heterotopii) se klade důraz na pamět' individuální, personifikovanou. Vzpomíná na to, jak byly oceňovány jeho mimořádné až zázračné (iracionální) schopnosti. Tvrdí, že prošel kómatem a dostal se až do světelného tunelu. Mluvil s Bohem, kterého přesvědčil, že má ještě mnoho světských povinností. Následně pomáhal $\mathrm{v}$ nemocnici těžce nemocným pacientům, nebot' dovedl rozpoznat vážnost zdravotního stavu a dokonce radil primáři, co by měl vykonávat. Jeho slovo platilo jako osudová věštba. Téměř se zdá, že si něco osvojil z př́běhů o biblickém zázraku a uzdravení nemocných, někdy se bezděčně připomíná mýtus o duši mrtvých. Využívá se také numerický systém, jak jej známe z pohádek: např́klad když radí, co dělat pro zdraví, nebo přikazuje, co musí být dodržováno, aby byl odvodněn a zánět odstraněn a nastalo kouzlo uzdravení. Nepřímo se tak vzývá lidové léčitelství, které se v romských praktikách objevuje s velkou četností, což souvisí s důvěrným poznáním př́rodních zákonitostí.

V jeho vyprávění se vyskytují modely tradičního chování a jednání Romů dnes již nejstarší generace. Například je v něm rozvíjena představa, že dobrý Rom je všude doma, vždy se domluví, že si Romové vzájemně pomohou, at' jsou kdekoliv. Poměrně lehce je možné rozpoznat, která informace je pro Romy cenná natolik, že si ji předávají, aby nebyla zapomenuta. $\mathrm{V}$ jeho podání se neustále propojují a vzájemně prostupují příběhy, které souvisí s dějinami rodu a romství v Evropě dvacátého století. Některé události jsou sdělovány útržkovitě, nejsou popisovány $\mathrm{v}$ celkovém vývojovém proudu a detailně. $\mathrm{V}$ jejich případě nabývá na významu obrazová stránka a fantazie vnímatele. Může se jednat o pravdivé výroky, avšak již tím, že vypravěč se o něčem zmiňuje jako o budoucnosti, třebaže se to přihodilo v minulosti, stávají se nadčasovými.

Stabilním elementem ve Ferkově životě zůstává přítomnost, jevová realita, spojená s pokrevně bohatě rozvětvenou rodinou, s něčím stále se obměňujícím, živým, regenerujícím. Setkávání doprovází radost, že se vidí, že se jim nic od minula nestalo a brzy zase nastane príležitost $\mathrm{k}$ pohostinství a veselí. Pak se vzpomíná, zpívá a tančí. Frekvence některých reakcí, slov na uvítání a opakování motivů tady souvisí s mentální složkou romské komunity, běžné je oslovování př́buzných slovy bratře. Ukazuje se, že zvolený textově-vizuální postup je nosný. Nic se neidealizuje, ale ani nekarikuje. Ferko má své typické rysy, které zastupují povahové znaky osobností z řad starších bohatších Romů. Nepostrádáme individualizaci, ani odlišení od jedinečných osobností. Jako dovětek autoři svazku uvádějí:

Během deseti měsíců od návratu ze Švédska se Ferko šestkrát přestěhoval, z toho dvakrát na místa, kde bydlel v době naší společné práce na knize. Dnes žije s Renatou Brendou a vážně nemocným bratrem Jožkem v Jablonci nad Nisou. V dubnu 2010 prodělal infarkt, naštěstí bez následků. Dcera Růženka nadále pobývá v Itálii. Ferko nepřestává snít, že jednou odjede za svými bratry do Anglie nebo Švédska.”

Albína - př́iběh lásky, která hory přenesla (O přibjehi; Ferko, 2010).

Albína, romská krasavice pocházející z Rudňan z východoslovenské romské osady, zastupuje střední generaci Romů. Pochází z místa, kde všichni romští obyvatelé měli práci a snažili se postavit si zděné domky. Vyučila se na textilním učilišti v Liberci. Jako osmnáctiletá se provdala za nemilovaného muže a přestěhovala se do osady Hermanovce, do chatrče uplácané z hlíny a proutí, kde zkraje musela žít s tchyní, pak její muž s kamarády postavil samostatnou chatrč. Snila o 
tom, že se jí někdy podaří odejít z rodiny Červeňákových a netušila, že k tomu dojde až po dovršení její třicítky, kdy již bude matkou sedmi dětí a vdovou. Manžel pod vlivem těžkých depresí a ze žárlivosti spáchá sebevraždu.

S Karlem se seznámila v roce 1998, v době povodní, kdy do postižených oblastí přijížděli dobrovolníci. Je jedním z trojice Čechů z humanitární organizace Člověk v tísni. Společně s Jardou a Klárou pronikne do jinak pevně sociálně sevřené komunity olašských Romů, nahlédne do jejich obtížně pochopitelných vnitřních zákonů, které souvisejí s patriarchálními vztahy velkorodin. Překvapí ho, stejně jako čtenáře, někdy až neuvěřitelně přežívající zvyky. Např́iklad Albínin manžel vyžaduje, aby se nikdo nikdy nedotkl některých předmětů. Např. nesmí nikdo použít jeho talíř, lžíci a hrnek. V osadě se dodržuje, aby manželka připravila pro svého muže alespoň jednou za den vařené jídlo, proto odmítá jíst kdekoliv jinde než doma. Ženina povinnost v romských rodinách byla odjakživa spojena s úkolem nasytit své děti a manžela. Muž na východním Slovensku v romských rodinách stojí $\mathrm{v}$ čele rodiny a jídlo dostává jako první. To se po staletí tradovalo a přenáší se dodnes z generace na generaci. Ř́íká se, že když žena chytila rybu, polovinu dostal muž a polovinu děti. Na ní nezáleželo, mohla se napít vody (Hlebová 2010, s. 47).

Albína je svázána nepsanými tradicemi, pravidly a zvyklostmi, které lze jen obtížně porušit, protože se v rodinách nadále rozlišuje mužská a ženská sociální role, na druhé straně je od mládí přitahovaná svobodomyslností a životem mimo slovenskou romskou komunitu. Vnitřně touží po opravdových a silných vztazích, po lásce a úctě muže $\mathrm{k}$ ženě. Její životní příběh je plný vnitřních rozporů. Po každém útěku z chatrče, zvláště když je krutě zbita, se stejně musí vrátit, protože nemá kam jít. Chtěla by se přátelit s neromskými ženami jako kdysi v učilišti v Čechách, avšak ve východoslovenské romské osadě žije v izolaci a je žárlivým manželem kontrolována na každém kroku. Touží po svobodě a lásce, ovšem manžel Baník, jinak pracovitý a hodný člověk, ji hlídá a bez př́ičiny nejméně jednou za měsíc Albínu krutě zmlátí.
Do Albínina stereotypního a ubíjejícího života vstupuje zcela nečekaně ideální muž - Karel, intelektuál, syn vzdělaných rodičů vědců. Sám vystudoval několik oborů na pražských vysokých školách; později se skutečně stal zakladatelem bratislavské pobočky Člověk v tísni a zplnomocněncem vlády Slovenské republiky pro romské komunity. Karel se do Albíny vášnivě zamiluje, ona jeho cit bezhlavě opětuje. Po různých odlukách a zvláště po smrti Albínina manžela se s ní ožení. Mají spolu syna Fredyho. Karel však stále někam jezdí, angažuje se v Kosovu, Albínu vidí nanejvýš jednou za měsíc. Situace se změní, když se Albína se čtyřmi nejmladšími dětmi nastěhuje na statek v Bernaticích na Javornicku, aby Karel mohl pracovat opět na univerzitě v Praze a mohl dojíždět domů alespoň jednou za týden. Na závěr, jako kdyby v dodatku, zastihneme oba doma v Javorníku. Albína se vrací ze Slovenska, kde byla na týdenní návštěvě své dcery, připravuje večeři a zlobí se, že Karel ani nenakoupil. Jedná se o běžný manželský duel, který je svým obsahem bezvýznamný, avšak svědčí o rovnoprávnosti.

Osudová láska této dvojice překonala všechny kulturní stereotypy a zatlačila do pozadí předsudky v chování obou komunit - Romů a Neromů. Stereotypizací se myslí povrchní charakteristiky, které nejsou vedeny personálně, nepřihlíží se v nich $\mathrm{k}$ individuálním př́ístupům a subjektivním pocitům postav. Předsudky s sebou nesou nepříznivé, negativní, nepřátelské postoje, názory a mínění, které souvisí s problematickým hodnocením vzájemného spolužití. Albína zaujme Karla svou osobností, otevřeností, temperamentem, vřelostí a bezprostředností. Nežije jako ostatní z romské komunity, to je ze dne na den, jejím největším bohatstvím je věrnost a oddanost tomu, koho miluje, schopnost sdílet s druhým radost i starost. Albína svou láskou naplňuje model romantických telenovel. Překonává různé překážky, avšak její láska hory přenáší. Když Albína o sobě vypráví, uvědomuje si sebe a kupodivu nepoužívá klišé. Způsob jejího sdělování je velmi střízlivý, je spojen s hloubkou vztahů a prístupem ke světu, s tlumenou deziluzí. Nejde o odkrývání něčeho nového, ale o rovnoprávné vymezování se ke spolužití. Závěrečný rozhovor mezi Albínou, čtyřnásob- 
nou babičkou, a Karlem, který je nadále zcela pohroužen do své práce, není romantický nebo idylický, zato působí realisticky.

Kresebně nejsou vidět rozdíly v provedení svazku Albina a svazku Ferko, spíše je nápadný rozdíl v textové části. Některé repliky postav jsou napsány dvojjazyčně, romsky a zkomolenou slovenštinou. Počet dialogů vedených romsky slábne, spíše se objevují záznamy psané obecnou češtinou podle toho, o jakou situaci se jedná. Fabule př́běhu je sama o sobě velmi jednoduchá, a kdyby v ní nesehrály svou roli dvě tragické události (povodeň a smrt), možná by ani nepůsobila věrohodně a byla jen o tom, jak se protiklady přitahují. Stala by se př́během o naplněné lásce. Černobílé ilustrační zpracování komiksu s romskou tematikou je ukázkou toho, jak výtvarné sémantické pole $\mathrm{v}$ komiksovém ztvárnění nemusí sehrávat ústřední místo, ale spíše odpovídá výtvarnému rukopisu tvůrce. Tam, kde by se zdlouhavě líčil zevnějšek, objeví se portrét ženy s bohatými vlasy, jinde, kde by se obtížně hledal výraz pro milostný vzmach, stačí zobrazit vášnivé objetí dvojice. Přri prudké výměně názorů postačí napsat texty v bublinách, místo zdlouhavých popisů osad a staveb chatrčí spatříme ilustrativní kresbu.

Komiksové provedení Ferka a Albiny nepochybně oživí zájem o romskou problematiku, idea soužití je v nich mnohovrstevnatě zúročena. V Albíně oceňujeme, že se jedná o kolektivní výtvor, v němž je vše promyšleno (od námětu po realizaci). Svazek má blízko ke „grafické novele", v níž se postihují autorské modely autobiografické a introspektivní. Svou úlohu sehrává spíše scénář, idea a obsah než komiksová forma. Na zajímavosti nabývá, že je odlišen text v bublinách, které zpravidla bývají na bílé ploše. Ve Ferkovi se objevují klíčové momenty a plocha bubliny je vybarvena žlutě, na rozdíl od Albiny, kde jsou plochy růžové, snad analogicky shodné s milostnou zápletkou. V obou svazcích nechybí závěrečný dovětek o dalších osudech autentických postav.

\section{Keva - př́běh nenaplněných možností}

Třetí prríběh je o dívčím dětství a dospívání. Keva se narodila zcela symbolicky 17. listopadu 1989 v Praze na Smíchově. Je ovlivněna spíše módními trendy a vzhledem světových filmových hvězd než romskou tradiční kulturou. Romsky nemluví, češtinu považuje za svou mateřštinu. Nedělá si ani starost se svou romskou identitou, ale ani s identifikací. S kamarádkami neromského původu si záměrně prohazují štítky se svými jmény, aby si je v okolí pletli. V její charakteristice se objevují nové rysy. Nejde jen o stereotypy, s nimiž se setkávají romské děti ve škole ve styku s učiteli, ale spíše o sebeakceptaci. Po dobu, kdy žila v Praze, si Keva sama vybírala z mnoha možností. Po odchodu na venkov je ovlivňována více svou rodinou a náhodným setkáním s lidmi, včetně členů jehovistické sekty.

Slovní zásoba Kevy je bohatá a sémantická spjatost slovní výpovědi mnohdy přesahuje obsah ilustrované situace. Zaujme nás spíše násobená obtížnost dospívání a analogie se vztahovým a generačním modelem těch lidí, kteří se ocitnou na pokraji bídy, opakovaně se setkávají s nedůvěrou okolí a podceňováním. Když se mimo Prahu dostává do zvláštní školy, protože jinde není místo, brzy tam zjistí, že je dívkou nadprůměrně inteligentní a stane se spíše černou ovcí. Začalo to, když měla dvanáct let a žili chvíli ve vesnici Lubné. Tady Keva poprvé pocítila, že si nerozumí s učitelkou, kterou provokuje svými odlišnými reakcemi i vědomostmi, a nabyla pocit křivdy. Kevino největší zklamání př̀dstavují požadavky na zvláštních školách, kam jsou romské děti automaticky převáděny. U nich učitelé dávno rezignovali a pořádně ani nevyučují. Keva si sice uvědomuje, jak je dủležité vzdělání a dobře placené pracovní místo, avšak stř̌́dání škol a institucí (odstrašující je napřr. rakovnická škola), neustálá změna bydliště a seznamování se s novými spolužáky jí neprospívají. Začala se spolužáky společně "hulit", neučí se, končí na učilišti, které si honosně říká, že připravuje pracovníky pro telefonní techniku, avšak místo praxe tady ořezávají kabely, aby se získala měd', nebot' barevné kovy se výhodně zpeněží. Pozoruhodným vnitřním mezníkem pro Kevu se 
stane setkání celé rozvětvené rodiny na pohřbu báby Jolany, kde si dívka poprvé uvědomuje sílu starobylých romských tradic.

Kevin životní př́iběh je všední až banální, není ani co vyprávět. Pozoruhodnou se stává spíše zvolená optika při zpracování látky. Sledujeme málomluvnou dívku jako někoho, kdo je odsouzen $\mathrm{k}$ pasivitě. Dostává se do blízkosti otevřených rasistických projevů, musí čelit lákadlům, jakými jsou drogy, jimž někteří kamarádi propadli. Některé obrázky vznikly domalováním fotografické předlohy portrétů, někdy jsou kresby prosvíceny bělobou, působí expresivně, používá se rozdílná kresebná technika, převahu má bílá, černá a bleděmodrá barva. Mnohdy je kresba záměrně zjednodušená. Jinak je třeba ztvárněno, co Keva dělá, nad čím přemýšlí, co zrovna čte. Mimochodem vidíme, že má před sebou obrázkovou knihu v komiksové podobě.

Na koncích každého knižního svazku jsou realisticky nakresleny figury ústředních postav a dokumentárně je sděleno, co dnes dělají Kevin př́iběh končí, když se chystá na svatbu s klukem, kterého jí dohodily sestry. V jeho rodině nyní žije. Dlouhý čas si zkracuje čtením něčeho, čemu se v minulosti několikrát ubránila - jehovistických knížek. Kdo ví, kam se její vnitřní cesta bude ubírat!

Komiksová trilogie $O$ přibjehi není grafickým románem, ale ani dokumentačním politickým komiksem ${ }^{4}$. Převažuje v něm ,sociologický vhled”. Romská problematika je složitá, přesto se v této formě zpracování stává vhodnou látkou, nerezignuje se na složku pocitovou, ale ani na vzdělávací. Př́iběhy vedou $\mathrm{k}$ dosud netradičnímu a typologicky odlišnému osvojení reality, nebot' na rozdíl od jiných zpracování by mohly najít odezvu také u romského etnika. Jestliže jsme zvolili různé přístupy (včetně sémiotického), přinášející důkladné popisy a charakteristiky postav v komiksové „,̌reči” odkazujeme jak na téma a žánrovou specifičnost, tak na modální kategorie.

\footnotetext{
${ }^{4}$ Označení přebíráme z publikace Petera Karpinského 2014
}

\section{Nejisté domovy}

České komiksové př́iběhy první a druhé komiksové řady trilogií se netají tematickou popularizací, jsou vybudovány na prezentaci vybraných postav žen a mužů. V prvním cyklu jsou to Ferko, Albína a Keva, ve druhém cyklu Michal, Honza a Lila. Gendrový vztah je v nich vyvážený, stejně jako generační polarita dospělí a děti - děti a dospělí. Rozdílnost spočívá $\mathrm{v}$ tom, že v Nejistých domovech je pohyb dětí omezen na dětské domovy a jejich prostor, prritom jsou romskými dětmi považovány jako něco cizí, obtížně přijatelné, nebot' pevně stanovený denní řád není romským dětem vlastní. Každou neděli čekají, kdy si pro ně blízcí př́ibuzní přijdou. Obě trilogie usilují o to, aby se typologicky přibližžly některým dominantním emočním projevům a povahovým rysům Romů. Na základě reakcí konkrétních postav tak spíše porozumíme romipenu (romské identitě). Př́běhy působí civilně, věcně, jsou bez sentimentu.

\section{Ašta šmé a institucionální podpora}

$\mathrm{Na}$ vzniku komiksových trilogií s romskou problematikou o dospělých Romech $O$ přibjehi (Praha: Nakladatelství Karolina Voňková - Lipnik, 2010) a na ediční řadě o romských dětech a dospívajících, které vycházejí s názvem Nejisté domovy (České Budějovice: Ašta šmé, 2016), se podílely jistě nikoliv náhodou opět romistka Máša Bořkovcová (1977) a sociální antropoložka Markéta Hajská (1976) a komiksový scenárista a výtvarník Vojtěch Mašek (1977). Dohromady vytvořili spolek s názvem Ašta šmé, který se snaží beletrizovat a popularizovat životy Romů. Knihy vyšly nejdřive s podporou Evropských kulturních fondů, později pomocí grantu z Islandu, Lichtenštejnska, Norska a za finančního přispění Velvyslanectví USA v Praze. Jedná se o stejnou osvědčenou autorskou sestavu, která tímto obohatila o novou formu zpracování nejen komiksovou tvorbu, ale také narativní sociologii. Nejde jen o to, že přicházejí se sdělnějším zobrazováním komplexnějších problémů společenských a sociálních, ale u mnoha témat se můžeme zastavit a začít uvažovat o jinakosti a ci- 
zosti, o stírání rozdílů mezi Romy a Neromy, a také o etických hodnotách, nebot' člověk je bytost chybující. Určitě bylo zapotřebí připravit si předem otázky a problémové okruhy, ale jindy stačilo především naslouchat, protože východiskem se staly autentické životní osudy, záznamy historek, které nesly stopy až surrealistické nadsázky, připomínaly černý humor, avšak byly vylíčeny s patetickým nádechem. Například Ferko líčí nehodu svého otce horníka v dole a následující operaci v nemocnici jako horor. Měl podle něj hlavu otočenou dozadu. V něčem jeho líčení připomíná romské pohádky, které čtenáři mohou připadat málo poetické. Životní př́iběhy „obyčejných” Romů, které se snaží odborníci zachytit v autentické podobě, si však vzaly do vínku, že nebudou nic korigovat a ponechají původní verzi tvrzení. $\mathrm{O}$ věrohodnosti nás přesvědčuje fakt, že zveřejňují např́iklad textovou zprávu, stížnost nájemníků kvůli nepořádku ve Ferkově bytě. Společně s ním se autoři komiksu starají o řešení a hledají nový byt, kde by mohl žít se svou manželkou a nemocným bratrem. Ptají se, zda chce Ferko pokračovat ve vyprávění. Ten souhlasí, ale „ne nasucho”, proto se přemíst'ují do hospody. Jedná se o postup ozvláštněný tím, že se nepouživá obvyklá explorační dotazníková metoda, naopak se nechává volný průchod myšlenkám, vzpomínkám a historkám. Zaujme nás, když se vrací k tomu, jak přišli první Romové do Rožkovan na východním Slovensku, odkud Ferko pochází. Výpovědi nejsou korigovány, takže se stává, že doprovodné obrázkové ztvárnění působí až dramaticky.

Komiksová trilogie $O$ přibjehi přibližuje badatelské výsledky specialistů a činí tak popularizující formou. „Příběhy”, a to v podobě „malých soukromých dějin”, jsou novátorské v oblasti romistických a romologických studií, nebot'v nich dochází k propojení několika fenoménů. Např. se problém přibližuje na základě konkrétního životního osudu, přiznává se vliv a působení společenských organizací a institucí, které by měly vést $\mathrm{k}$ lepšímu porozumění $\mathrm{s}$ minoritou na bázi vzájemného poznávání a tolerance. Jedná se o osobitou a výrazně odlišnou mediální formu, která byla vyznamenána Cenou Muriel za rok 2010 (Nejlepší komiksový scénář). Zapíše se do dějin českého komiksu, nebot' se vztahuje k českým a slovenským reáliím a k určitým př́rodním událostem, jakým byla stoletá voda - povodeň v roce 2008. Ve svazku Albína se přírodní katastrofa podílí na radikální změně v životě romské osady, kam přicházejí pomáhat neromští dobrovolníci z mezinárodních občanských spolků a sdružení.

Stále více se komiks přestává přijímat jako žánr okrajový, jako projev populární kultury zábavného typu, nebot' přibývají díla založená na souvztažnostech sociologických nebo estetických studií v multimediálních prostorech. Tento typ komiksu, podobně jako další Maškovy práce ${ }^{5}$, patří k těm, které popírají omezené námětové a tematické možnosti komiksu, pochybují o způsobu zpracování, rozostřují hranice mezi vysokým a nízkým, velkým a okrajovým uměním.

Obě trilogie $O$ pribjehi a Nejisté domovy se staly pozoruhodným př́kladovým materiálem, který souvisí se způsobem života a životní filozofií Romů. Lze je rozdělit do skupin odkazujících k tradici a romskému hodnotovému systému, k romské mentalitě i stereotypům, jímž podléháme, když se popisuje př́stup $\mathrm{k}$ životu, chování a jednání Romů (Ševčíková 2008, s. 37). Když v roce 2016 vyšel svazek Nebud' jak gádžo!, byl kresebně doprovázen Františkem Loubalem. Skupina Ašta šmé se tak otevřela další spolupráci, rozšiřuje své řady ilustrátorů. Marek Pokorný výtvarně připravil svazek Silnějši než někdo, na vzniku třetího svazku druhé řady se podílela výtvarnice, zpěvačka a raperka Lela Geislerová (Lili a dvě mámy). Autoři se pokusili textem a obrazem zprostředkovat osudy a životní příběhy romských dětí, které prošly spletí nešt’astných rodinných peripetií. Pronikáme do problémů vzájemného soužití Romů, uvažujeme o vztazích mezi minoritní a majoritní společností, prostřednictvím příběhů romských dětí si uvědomujeme negativní důsledky institucionální separace. Protagonisté prríběhu rovněž vyprávějí své životní příběhy a je úspěch, že souhlasili se zveřejněním některých naprosto soukromých informací. Ve

\footnotetext{
${ }^{5}$ Scenárista a komiksový kreslír je autorem úspěšných knih Svatá Barbora (2018) a Sestry Dietlovy (2018), které byly oceněny jako nejlepší komiksové knihy roku.
} 
svazku Nebud' jak gádžo! nechybí ani dokumentární fotokopie výňatků z úředních vyjádření a odborných posouzení, které doprovázely kroky na ochranu dítěte. Informace o nich se odlišují typem a velikostí písma a umístěním textu na samostatné stránky. Důvěra vložená do autorů komiksu a projektu, který v ničem nezastírá účelovost, způsob, jak je realita uchopena, představuje krajně náročný proces, nebot' vyžaduje poučenost iniciátorů a řešitelů projektu, stejně jako určitý životní nadhled a interpersonální schopnosti vypovídajících. Cílovou čtenářskou základnou se ve druhé trilogii mohou stát děti a dospívající mládež romského i neromského původu. Obě trilogie zaujmou svou šířkou a hloubkou výzkumného pojetí, přitom se autoři netají popularizací problematiky a tematickým výběrovým př́istupem. Účinek může být několikerý. Jednak se čtenáři vedou k získávání nových interkulturních poznatků, minority motivují k sebeuvědomění si své identity a majoritu vyzývají k etnické toleranci.

\section{Nejisté domovy}

Trilogie Nejisté domovy zahrnují životní etapy tř́i vybraných autentických postav (Michala, Honzy a Lili). Zmiňuji se léta předškolní, školní a dospívající, sledujeme životní peripetie hrdinů až do adolescence. Události se odehrávají po roce 1989 a směřují do současnosti. Romské děti bezděčně prožívají svou jinakost, která aktivuje i uvolňuje emoce a motivace. Uzlovými body se stávají př́chody dětí do dětských domovi̊, kde se zkraje cítily lépe a chvílemi byly možná št'astné, protože začaly být zahrnovány dosud nepoznanou péčí. Dočasné návraty do romských rodin a pokusy najít pěstounské rodiny jim však většinou neprospěly. Zmiňují se situace, kdy se formují vzájemné vztahy mezi učitelem/vychovatelem a romským dítětem, které se budují povlovně, na bázi překonávání nedůvěry vůči neznámému. Děti jsou rády, když je někdo z rodičủ navštíví, vezme si je na několik prázdninových dní domů. Zpočátku se až podivují, co všechno si doma mohou dovolit. Mlsat a dívat se od rána do večera na televizi, poslouchat, co si vyprávějí dospělí a skákat do jejich rozhovoru atd.
V malých bytech se mnohdy tísní několikanásobný počet př́buzných, kteří přijiždějí a odjíždějí, baví se, pokud stačí peníze.

Nezastírá se, že romské matky si nedělají těžkou hlavu s umístěním svých malých dětí v dětských domovech, často je ani nenavštěvují. Když se občas objeví, vymýšlejí si důvody, proč se tak stalo, dokonce vyvolávají konflikty s vychovatelkami. Nicméně potomci je nepřestávají milovat a stačí, když nacházejí alespoň malé zrnko pravdy v tom, co tvrdí, aby vše odpustili. Opakují se nepřiměřené situace, zanedbávání péče, návštěvy sociálních pracovnic a opakující se odebrání romských dětí do ústavů. Střídají se poměrně krátké časové intervaly, kdy pobývají v pěstounské péči. Výjimečný se stává Lilin životní př́iběh, protože se dostává do pěstounské rodiny až ve svých deseti letech. Nikdo jí netají, že má svou romskou rodinu, ale to neznamená, že by nemohla mít dvě mámy. Pěstounka podporuje Lilinu přirozenou inteligenci, neustále ji povzbuzuje a stimuluje k výkonům ve škole, přitom ji mrzí, že dívka se sebepoškozuje, je spíše uzavřená do sebe. Zobrazení př́iběhu značně pomáhá výtvarné zpracování Lely Geislerové, které barevně vyjadřuje pocity a nálady dívky. Obrázky vedou k celkové poetičnosti knižního svazku. K etnické jinakosti, která nestojí v centru pozornosti, se připojují problémy s dospíváním a vnitřní zápasy Lili, násobené vnitřní, zřejmě temnější strunou její osobnosti.

V komiksech Nejistých domovů, v druhé řadě „romských trilogii””, se opakovaně zobrazují kratší pobyty dětí u vlastních matek, s nimiž menší děti navždy spojují představu domova. Romské děti na rozdíl od neromských neberou za svou autoritu učitelů a vychovatelů, mají problémy s domovy mládeže, sžívají se zde jen pomalu s nastoleným pevným denním řádem. Pocitují citelněji křiivdy, které zažily v prostředí školy a v dětských domovech než v romské rodině. Zvláště ve svazku Silnějši než někdo je zobrazována problémová interakce a komunikace, využívá se elipsa. Hrdina v čase záchvatů jedná natolik emocionálně, že se jeho psychické zkraty zobrazují beztextově. Výjevy doprovází nanejvýš citoslovce, takže čtenář si musí mnoho domyslet. 
Zatímco Michal v černobílé podobě svazku Nebud' jak gádžo! vyvolává sympatie svým vzhledem a získává si okolí pohybovou šikovností a přítulností, barevně vyvedený Honza Oračka ze Silnější než někdo upoutá výrazně tmavší pletí, věčnou zamračeností a zpupností. Bezpečně ho poznáme podle modrého oblečení a kšiltovky. Od útlého dětství má vážnější psychosomatické potíže způsobené řetězcem traumat. Především podléhá náhlým agresivním záchvatům, které mohou být z okolí vyprovokovány nečekaně: nenápadným gestem, tóninou hlasu (např́klad dominantním postojem učitelky nebo vychovatelky), vnitřním nesouhlasem. Chlapec trpí nespavostí, malou soustředěností, přepadávají ho záchvaty vzteku, neumí se podřídit autoritě. Sám Honza svým výkyvům říká ,raply”.

Tam, kde Michal bez větší námahy získá náklonnost okolí, jedna z vychovatelek si chlapce často bere k sobě domů a většinou u ní tráví Vánoce, o Honzu nikdo nestojí. Michalova oblíbená vychovatelka zabrání, aby začal chodit do zvláštní školy a byl vystaven menším učebním nárokům, protože správně odhadne jeho kognitivní vývojové možnosti. Michalův příběh bychom mohli nazvat jako št'astnější. Honza se od malého kluka potýká s problémy, svými projevy budí spíše rozpaky a antipatie, později se neobejde bez antidepresiv. Prostředí, v němž malé romské děti načas žily, se mnohdy značně podílí na tom, jak později jednají. Michal dostává v domově př́iležitost dělat věci, které by za jen trochu jiných okolností dělat nemohl. Nakonec úspěšně dokončí středoškolské i vysokoškolské vzdělání. Černobílé zpracování sešitu Nebud' jak gádžo! ovšem nevyznívá prvoplánově. Michal není žádným andělem a jeho návraty do minulých dní se vzpírají iluzi netečného záznamu. Vypráví o sobě, slyšíme jeho hlas v bublinách, čteme informace z jiných stran. Zvládá však snáze sérii dílčích životních zkoušek. Stává se obligatorním průvodcem svého př́iběhu, ale zastává také funkci narativně - realizační. Nalézá svou cestu. Michal působí vyváženě, třebaže také on prošel pubertálními etapami vzpoury. Ve srovnání s Honzou vyznívá kladně, protože ten se chová nevyzpytatelně, nedovede se podřídit autoritě dospělých, ale není ani oblíben mezi dětmi. Honza se opakovaně dostává do izolace a chce na sebe alespoň upozornit agresí. Existují však také fáze zklidnění. Pravidelně, $\mathrm{v}$ průběhu letních táborů, se setkává $\mathrm{s}$ dětmi $\mathrm{z}$ běžných rodin, pocit'uje blízkost k prrírodě, imponuje mu rozhodnost a tělesná zdatnost vedoucích, podřizuje se silné autoritě. Všemu, co na táboře vykonávali, beze zbytku věří. Letní pobyty patří mezi jeho nejšt’astnější prožitky $\mathrm{z}$ dětství.

Oba chlapci jsou diametrálně odlišní povahově, spojuje je pouze osud romského dítěte. Michal (první svazek) i Honza (druhý svazek) druhé řady „romské trilogie” žijí v jiných dětských domovech, představují odlišné typy a vyvíjejí se nezávisle na sobě. Shodu můžeme spatřovat snad jen $\mathrm{v}$ tom, že se stávají hrdiny svého vlastního života, získali odstup a nadhled a dovedou autorům komiksu o sobě klidně a sebevědomě vyprávět. V obou svazcích se neopomíjí ani pohled Neromů. ${ }^{6} \mathrm{~V}$ dospělém životě potřebuje Honza mít vzor, jinak lehce padne do léčky opakovaných půjček, krádeží kovů, propadne hracím automatům a jiným lákadlům. Zkraje je partou kluků šikanován, pak se vývoj zlomí, stoupá jeho fyzická kondice a sám nabývá přirozenou autoritu, dovede se o sebe postarat.

Honza má problémy s adaptabilitou, Michalovi zase hrozí pocit nadřazenosti. Prochází obdobím, kdy jen čte, studuje, mnoha věcem rozumí a následně podceňuje ty druhé. O to spíše mu vadí, když se na něj někdo dívá s despektem. Například na jeho promocích vzbudil pozornost otec s partnerkou, protože se oba oblékli do nápadně blýskavého oděvu a na rautu někdo ze zúčastněných prohodil, co tam oni dělají. Michalův př́iběh je nejen doplňován zapůjčenými úředními dokumenty, ale jeho výpověd' rozšiřují hlasy rodičů a dalších příbuz-

${ }^{6}$ Označení Rom a Nerom má zdůraznit protikladnost, třebaže druhý termín je nepřesný. Termíny Rom, romský jsou dnes chápán jako politicky a společensky korektní, zatímco výrazy Cikán, cikánský, uživaný ve starší literatư̌e jako paralelní (Horváthová 1954), s sebou stále více nesou pejorativní označení. Třebaže je jeden díl druhé trilogie Nejistých domovů spojen se slovem gádžo, je v něm podobně jako jinde chápán romský pohled na sociokulturní determinanty. Termín Rom vstoupil do celosvětového povědomí až díky osvětové činnosti Mezinárodní romské unie (International Romani Union). 
ných. Komiks je kresebně i textově srozumitelný a přehledný, dobře se čte i obrazově snadno vnímá. K věrohodnosti přispívá, je-li viděn také ze stinné stránky. Když Michal po promocích navštíví dětský domov, kde mu kdysi v dětství byli všichni nápomocni a podporovali jeho talent, nepocit’uje žádný vděk, není schopen sdílet radostné vzpomínky, připadá si zde spíše jako cizinec nebo ten, kdo chce místo vytěsnit ze své paměti.

$\mathrm{K}$ vyjádření Honzových psychických propadů musel výtvarník Marek Pokorný zvolit určitou symboliku. Staly se jí celostránková zobrazení pádů do sněhu nebo Honzovo pohlcení zelení. Na těchto stránkách neplatí čtení zleva doprava, můžeme je číst všemi směry. Výtvarně je Pokorného komiks velmi zdařilý. Více než obvykle se pracuje s různými rozměry panelů a bublin, některé sekvence nejsou opatřeny textovou částí, dominantu tvoří figury, někdy je umístěna do rámečku jen textová část. Zpracování Honzova životního příběhu Silnějši než někdo se jeví náročnější nejen tematicky (časově a prostorově), typologicky a vztahově, ale také výtvarně - narativně a vizuálně. V obrazových polích je zachycen pohyb vnějškový i vnitřní, dochází zde ke kongruenci, k opakovanému zachycení stejného prvku (vypjaté emoce) v odlišných situacích nebo z jiného úhlu pohledu, s nabídkou odkazů na některé části. Někdy jsou do příběhu vložena obrazová pole, která zdánlivě s př́během nesouvisí, nebot' obraz v sobě nese významové přesahy. Předjímá, co bude následovat.

Nejbarevněji a nejharmoničtěji z trojice svazků vyznívá Lili a dvě mámy, ilustrovaný Lelou Geislerovou. Vizuálně se nezapře silné sdílení s hrdinkou a schopnost zachytit situační pointu. Lili byla odebrána rodičům ve čtyřech letech, když se zjistilo, že je zavírána do garáže s dogami a ty se o děvčátko starají lépe než matka. Na čas se sice vrátila domů, avšak v pěti letech byla opět odebrána a dostala se nastálo do dětského domova. Po pěti letech v domově zaznamenává čtyři roky v pěstounské péči. Lili zastihneme jako málomluvnou studentku gymnázia. Autorky komiksu nechávají vyprávět jednak dívku, jednak pěstounskou mámu, ale také Lilinu babičku, která právě přijede domů, protože žije v Německu. Pěstounka má s manželem pracu- jícím v Rusku dva velké syny a na otázku, proč se rozhodla pro pěstounství, odpovídá, že vždy chtěla mít děvče. Doplnění geneze, motivace při výběru života dětí však najdeme rovněž na záložce knihy. Tam autorky projektu uvádějí, že ,... důvody jsou pro to dva. Pěstounská práce nemá v Česku zdaleka takové společenské uznání, jak by si zasloužila. A za druhé, o peripetiích výchovy dětí s tíživou minulostí v nových rodinách se pořád ještě nemluví dostatečně. Tyto potíže přitom bývají tak velké, že čelit jim nepřipraveně, může způsobit dětem i pěstounům těžko zhojitelné rány" (Nejisté domovy; Lili a dvě mámy, 2016). Také tento komiks vyniká autenticitou a zároveň citlivým výběrem konkrétních situací, které mohou sehrát svou roli při řešení št’astných i nešt'astných konkrétních rozhodnutí. Zatímco Lili je málo sdělná, vypráví spíše o tom, co právě prožívá, zmiňuje se o kamarádkách, s nimiž si píše na facebooku, její druhá matka - paní Pekárková - působí vstrrícně a starostlivě, ráda vzpomíná na seznámení s Lili, nezapírá společné problémy a kolize, s nimiž se v proběhu let setkala. Ilustrátorka Geislerová má zkušenost s uchopením gendrového hlediska, vzpomeňme na její ironické stripy Zen žen, které vycházely v týdeníku Respekt a hrdinky komiksových povídek Jednou za život (2006), Křžžová cesta do sámošky (2009) nebo Magda (2010). Jsou malými psychologickými sondami. Také v rozhovorech Máši Bořkovcové s Lili, jinde s paní Pekárkovou a dále s Liliinou babičkou si uvědomujeme, jak významný podíl sehrává výtvarné zobrazení př́iběhu. V posledním svazku dominují spíše oblé tvary a tlumené barvy, upoutají neverbální signály, výrazy tváří, oči, polohy rukou, nebot' všechny dohromady napomáhají estetické úrovni knihy. Výtvarný rukopis Lely Geislerové zvyšuje myšlenkovou náplň tohoto svazku, posiluje sémantický prostor tématu, akcentuje vázanost s pointou a syžetovým tvarem textu. Kresebná technika je vystavěna na figurativních obrazech, třebaže zanedbatelné nejsou ani místa, které Lili vyhledává (opuštěný dům, hřbitov, odlehlá krajina s kř́žžem). 


\section{Závěr}

Obě „romské komiksové trilogie” představují progresivní nebo chcete-li hraniční mody, jež do sebe vstřebaly řadu odlišných žánrových prvků a postupů. Jestliže jsme formu zpracování nazvali hybridní, máme tím na mysli, že se v komiksech vzájemně snoubí dvě oblasti a dva styly (vědecký a umělecký), mísí se žánry (např. biografie, př́běhy ze života, grafická novela), koexistují v nich složky konstantní i doprovodné. Uplatňuje se zde postup blízký sociologickému záznamu autentické osobní výpovědi a postupy narativní fikce.

$\mathrm{V}$ př́bězích se prolínají odborná hlediska s literárními a literárně-vizuálními postupy. Textový scénář je základem pro vizuální zpracování, ovšem uplatňuje se také orální forma blízká slovesnému folkloru, připomínají se memoráty, stejně jako biografické př́iběhy. Setkáváme se zde s prostorovou metaforou, nebot' některé životní př́běhy se odehrávají v uzavřeném prostoru romské komunity, přitom z hlediska genologického připomínají rozvlněnou ,žánrovou krajinu” $\mathrm{s}$ různými ontologickými a antropologickými mody, psychologickými a sociologickými konstantami i diferenciacemi, které nejsme $\mathrm{s}$ to jednoznačně pojmenovat, protože se $\mathrm{v}$ české knižní kultuře běžně nevyskytují.

Více než kde jinde se v trilogiích potkáváme se závažností kladených otázek, máme co do činění se společenskou etikou a morálkou, slovem a obrazem se zachycují oboustranné projevy empatie i tolerance. Autorské týmy mají porozumění pro romskou identitu, stejně jako pro lidské slabosti a selhání, a to bez rozdílu přináležitosti $\mathrm{k}$ určitému minoritnímu etniku. Nic se v nich nebagatelizuje, ani nezveličuje, nikdo se neodsuzuje, ale ani neadoruje, spíše se pracuje s fakty a dokumenty a pritom se pomocí žánrových transmisí stírají vžité kulturní stereotypy a dosahuje se uměleckého účinku.

\section{Literatura}

B ořkovcová M., Mašek V., Hajská M., 2010, Keva, [in:] O přibjehi, Praha.

B oř k o v c ová M., H a j s á M., M a š e k V., P o k or ný M., 2016, Silněǰ̌si než někdo, [in:] Nejisté domovy, Praha.
Bořkovcová M., Hajská M., Mašek V., Loubal F, 2016, Nebud' jak gádžo!, [in:] Nejisté domovy, Praha.

B oř k o v c o vá M., G e i s l e r o vá L., H a j s ká M., 2016, Lili a dvě mámy, [in:] Nejisté domovy, Praha.

Ha j ská M., B ořkovcová M., M a šek V., 2010, Ferko, [in:] $O$ přibjehi, Praha.

F a n t o vá J., K o pá č E. (eds.), 2012, Nový český komiks (2000-2012), Praha.

F o r e t M., 2010, Mezi literárnem a výtvarnem: komiks jako obrazoslovný amalgám, „Česká literatura” LVIII, č. 5, s. 581-606.

F o r e t M., 2012a; Nejistá medialita komiksu, [in:] M. Foret, P. Kořínek, T. Prokůpek, M. Jareš (eds.), Studia komiksu. Možnosti a perspektivy, Olomouc, s. $85-95$.

F o r e t M., 2012b, Nová generace, nové světy, novi hrdinové, [in:] P. Kořínek, T. Prokůpek (eds.) Signály z neznáma. Český komiks 1922-2012, Praha, s. 300-333.

H 1 e b o vá B., 2010; Rómská identita (romipen) v rómských rozprávkách (paramisa), Prešov.

H o r vá th o vá E., 1964, Cigáni na Slovensku, Bratislava.

J a řáb o vá Z., D a vi dová E. (eds.), 2000, Černobílýs svět, Praha.

K a r p in s ký P., 2014, Poetika komiksu v texte a kontexte, Prešov: FF PU.

Korrín e k P., For et M., J a r eš M., 2015, V panelech a bublinách. Kapitoly $z$ teorie komiksu, Praha.

Kratochvil A., 2015, Mlha minulosti - vlaky duchů a strašidelná nádraži, "Tvar", č. 9, s. 12-13.

K r a t o c h v il A., 2014, Uvědomit si vzpominky vyžaduje př́běhy. O studiu paměti, traumatu a literatury, , Host” XXX, č. 2, s. 43-45.

Mašek V., Ha js ká M., B ořk ovc ová M., 2010, Albina, [in:] O přibjehi, Praha.

M a u th a u s e r Z., 1999, Estetika racionálniho žrení, Praha.

Nový český komiks (2000-2012), 2012, Praha: MK ČR.

R a kú s S., 2015. Poetika prozaického textu, Levoča.

R y a n o v á M. L., 2001, Narrative as Virtual Reality: Inmersion and Interactivity in Literature and Elektronic Media, Baltimore.

S m old e r e n T., M a r i n i E., 2003a, Gipsy, Den pro cara, Praha: BB Art Komiks. S mold e re n T., M a ri n i E., 2003b, Gipsy, Oči černé, Praha: BB Art Komiks.

S molde re n T., Marin i E., 2003c, Gipsy, Severské ohně, Praha: BB Art Komiks.

S molderen T., Marini E., 2004, Gipsy, Zázračná hvězda, Praha: BB Art Komiks.

Š e v č í k o vá V., 2008, Slyšet, citit a dotýkat se ...Romská hudba a hudebnost Romů jako pozitivni kulturni stereotyp a dominantni kulturní konfigurace, Ostrava.

Š i ák P., 2013, Úvod do studia genologie. Teorie literárního žánru a žánrová krajina, Praha. 